GrZEGORZ SMYK

(Lublin)

\title{
Zasady funkcjonowania rosyjskiego modelu biurokratycznego w Królestwie Polskim po powstaniu styczniowym
}

\author{
Prinzipien der russischen Bürokratie \\ im Polnischen Königreich nach dem Januaraufstand
}

1. Uwagi ogólne. 2. Status prawny biurokracji rosyjskiej. 3. Charakterystyczne cechy rosyjskiego modelu biurokratycznego. 4. Funkcjonowanie rosyjskiego modelu biurokratycznego w Królestwie Polskim po powstaniu styczniowym.

1. Allgemeine Bemerkungen. 2. Rechtliche Position der russischen Bürokratie. 3. Merkmale der russischen Bürokratie. 4. Die russische Bürokratie nach dem Januaraufstand.

Kryzys feudalizmu i rewolucje burżuazyjne, które w większości państw europejskich doprowadziły do powstania monarchii konstytucyjnych, ominęły Rosję. W drugiej połowie XIX w. Cesarstwo Rosyjskie pozostawało nadal państwem, które od czasów Piotra I i Katarzyny II przybrało formę scentralizowanej monarchii absolutnej. Reformy ustrojowe podjęte przez Aleksandra I na początku XIX w. pod wplywem przemian zachodzących $w$ rewolucyjnej i napoleońskiej Francji zmierzały jedynie do usprawnienia funkcjonowania aparatu państwowego i wyeliminowania zeń instytucji anachronicznych. Rozpoczęta przez Aleksandra II przebudowa ustroju państwa w duchu liberalizmu została zahamowana po jego tragicznej śmierci w $1881 \mathrm{r}{ }^{1}$ Ponadto reformy te nie naruszały fundamentalnej zasady ustrojowej państwa rosyjskiego, którą była absolutna władza dziedzicznego cesarza, skupiającego w swym ręku nieograniczoną władzę ustawodawczą, wykonawczą i do $1864 \mathrm{r}$. także sądowniczą. Wszystkie organy państwowe - zarówno istniejące, jak

\footnotetext{
${ }^{1}$ P. A. Zaj on czk owski, Prawitielstwiennyj aparat samodierżawnoj Rossini $w$ XIX w., Moskwa 1978, s. 137-139; L. B a z y low, Historia Rosji, t. II, Warszawa 1985, s. 87-100; L. Za c h a row a, Aleksander II, [w:] Dynastia Romanowów, Warszawa 1993, s. 345-360; M. S c z a n i e c k i, Powszechna historia państwa i prawa, Warszawa 1973, s. 542-548.
} 
i reformowane lub tworzone od nowa - powstawały jako instytucje shużebne wobec monarchy, w celu ułatwienia mu sprawowania tak rozległej władzy i merytorycznego uzasadnienia słuszności podejmowanych przez niego decyzji. Stosownie do swojego uznania, cesarz mógł rezygnować $\mathrm{z}$ posiadanych uprawnień $\mathrm{i}$ delegować je $\mathrm{w}$ dowolnym zakresie na poszczególne organy czy wybranych urzędników, na przykład namiestnika albo general-gubernatora. W ten sposób powstał w Rosji charakterystyczny dla monarchii absolutnych podzial władzy wykonawczej na „rząd” w osobie monarchy i ,,administrację”, czyli pozostałe podległe mu bezpośrednio organy. Samowładność, nieograniczoność i brak jakiejkolwiek kontroli czy odpowiedzialności były w Rosji podstawową cechą władzy cesarza i podległej mu administracji aż do początku XX w. Nie pozostało to bez wpływu na sposób działania organów zarządu cywilnego państwa i charakter biurokracji rosyjskiej².

Scentralizowany aparat panstwowy rosyjskiej monarchii absolutnej swoje funkcje spelnial dzięki zastosowaniu systemu biurokratycznego zarówno jako podstawy organizacji administracji, jak i zasady rekrutacji, wynagradzania oraz awansowania kadr urzędniczych. Jego głównymi cechami były - jak już zaznaczono - resortowy podzial kompetencji wykonawczych wszystkich organów zarządu cywilnego państwa, wielostopniowa struktura urzędów w każdym pionie administracji, hierarchiczna zależność organów niższego stopnia od wyższych i taka sama podległość służbowa urzędników, wykształcenie generalnych reguł postępowania w administracji. Przede wszystkim zaś system biurokratyczny wyróżniał zawodowy charakter administracji, której działanie było oparte na wykwalifikowanym i uposażonym przez państwo korpusie urzędników mianowanych, których stanowisko prawne zostało ujęte w osobnej ustawie o służbie cywilnej ${ }^{3}$.

W Rosji, tak jak i w innych państwach, przyjęcie biurokratycznego systemu organizacji zarządu państwa pociągnęlo za sobą konieczność zatrudnienia w aparacie administracyjnym znacznej liczby stałych, zawodowych urzędników tworzących korpus państwowej służby cywilnej, równoległy do korpusu zawodowej służby wojskowej. Inicjatorem utworzenia korpusu urzędników cywilnych w Rosji był Piotr I. Wzorując się na rozwiązaniach przyjętych w Szwecji i państwie brandenbursko-pruskim, ustanowił on

${ }^{2} \mathrm{H}$. I zdebski, Kolegialność i jednoosobowość w zarzqdzie centralnym państwa nowożytnego, Warszawa 1975, s. 66-68; P. A. Za jo n czk ow sk i, Prawitielstwiennyj aparat..., s. 192-217; W. G. Czernucha, Wnutriennaja politika carizma s serediny 50-ch do naczala 80-ch g. $X I X$ w., s. 118-135; M. S c zan ie ck i, Powszechna historia..., s. 548-549; K. G r z y bow sk i, Historic państwa $i$ prawa Polski, t. IV: Od uwlaszczenia do odrodzenia Państwa, Warszawa 1982 , s. 42-44.

${ }^{3}$ H. I zd e b s k i, Historia administracji, Warszawa 1984, s. 14-15; R. P i pe s, Rewolucja rosyjska, Warszawa 1994, s. 47-51; L. Bazylow, Historia Rosji, t. I, Warszawa 1985, s. 310; Z. Chmielewski, Narodziny $i$ rozwój biuralizmu na ziemiach polskich $w$ okresie zaborów, Zesz. Nauk. Uniw. Szczecińskiego [dalej ZN USz.] 1993, nr 113, s. 26-27. 
obowiązek odbywania przez całą szlachtę służby państwowej - wojskowej albo cywilnej. Służba cywilna rozpoczynała się w 15 . roku życia i formalnie miała trwać dożywotnio. $\mathrm{Z}$ obowiązkiem shużby cywilnej łączył się obowiązek uzyskania przynajmniej elementarnego wykształcenia. System ten nie dał się jednak dhugo utrzymać w praktyce ze względu na opór szlachty. Po śmierci Piotra I obowiązek służby państwowej został najpierw ograniczony, a w $1762 \mathrm{r}$. zniesiono go calkowicie. Nie oznaczało to jednak, że szlachta przestała w Rosji piastować ważniejsze urzędy; przeciwnie - to jej przedstawiciele stanowili podstawę biurokracji carskiej aż do początków XX w. Nieporównywalnie trwalsze od obowiązku służby państwowej okazało się wprowadzenie przez Piotra I w 1722 r. "Tabeli o rangach”, która podzieliła wszystkie stanowiska w służbie cywilnej, wojskowej, dworskiej i morskiej na 14 stopni. Shużbę rozpoczynano od najniższego stopnia, chyba że kandydat legitymował się odpowiednim wykształceniem. Dostęp do urzędów zapewniono również nie-szlachcie, która piastując urzędy określonych rang, nabywała prawo do szlachectwa osobistego lub dziedzicznego. „Tabela o rangach” w praktyce państwa rosyjskiego byla udaną próbą wprowadzenia typowo biurokratycznych reguł przyjmowania do państwowej służby cywilnej i awansowania urzędników w warunkach politycznej i spolecznej dominacji szlachty, która w innych państwach, na przykład w przedrewolucyjnej Francji, utrudniała należyte funkcjonowanie aparatu biurokratycznego ${ }^{4}$.

\section{2}

Powstanie korpusu zawodowych urzędników państwowej służby cywilnej wiązało się także z przyznaniem im samodzielnego statusu prawnego, którego normy zostały ujęte $w$ ustawie o służbie cywilnej. Jego główną cechą był publicznoprawny charakter więzi łączącej urzędników z państwem, którego istota wynikała ze sposobu nawiązania i rozwiązania stosunku urzędniczej służby publicznej, rodzaju oraz zakresu praw i obowiązków urzędniczych, a także rodzajów ponoszonej przez urzędników odpowiedzialności. O publicznym, a nie prywatnoprawnym charakterze nawiązania stosunku urzędniczego decydowal fakt, że dochodził on do skutku nie w wyniku kontraktu dwóch równych stron, ale na podstawie aktu administracyjnego - nominacji. Poprzez nominacje wladza państwowa wyrażała swoją wole jednostronnie, określając zarówno kompetencje, jak i sposób postępowania urzędnika, który wstępując do służby, nie mógł ich negocjować, a jedynie winien był je

\footnotetext{
${ }^{4}$ E. Amburger, Geschichte der Behordenorganisatin Russlands von Peter dem Grossem bis 1917, Leiden 1966, s. 54-56; H. I z d e b sk i, Historia administracji..., s. 43-46; L. B a z y low, Historia Rosji..., t. I, s. 310-314; L. E. Sze pi elew, Otmienienija istorijej. Cziny, zwania i tituly Rossijskoj Imperii, Leningrad 1977, s. 10-14.
} 
przyjąć bez żadnych zastrzeżeń. Także rozwiązanie stosunku urzędniczego, poza wypadkiem śmierci urzędnika, następowało na podstawie jednostronnej decyzji organu państwas.

Publicznoprawny charakter stosunków urzędniczych wynikał także z samej treści służby cywilnej, którą była realizacja zadań państwa i jego funkcji publicznych, wykonywana przez urzędników w imieniu państwa i na jego rachunek, w granicach powierzonych im kompetencji ${ }^{6}$. Jej odzwierciedleniem byl specyficzny dla tej grupy funkcjonariuszy państwowych zakres praw i obowiązków urzędniczych. $Z$ jednej strony obarczeni oni byli obowiązkami graniczącymi nawet $\mathrm{z}$ uszczupleniem ich wolności osobistych, jak na przykład wymóg zgody zwierzchnika na zawarcie związku małżeńskiego, z drugiej zaś posiadali uprawnienia niedostępne dla zwykłych obywateli. Do szczególnych obowiązków urzędników wynikających ze stosunku służby cywilnej należały: osobiste wykonywanie powierzonej funkcji, hierarchiczne posłuszeństwo wobec zwierzchników, zachowanie tajemnicy służbowej i państwowej, apolityczność, wierność i lojalność wobec monarchy i państwa oraz należyta konduita i noszenie przepisanego munduru służbowego. Ponadto wobec interesantów urzędnicy byli zobowiązani do szybkiego załatwiania ich spraw i poszanowania ich godności osobistej. Ze względu na pelnione funkcje urzędowe urzędnikom przyshugiwało: prawo do wymagania posłuszeństwa od osób prywatnych w stosunku do wydawanych przez nich w imieniu państwa poleceń i rozkazów, prawo do ochrony godności i honoru jako przedstawicieli władzy państwowej, prawo do noszenia munduru i prawo posługiwania się rangą $i$ tytułem odpowiednimi do zajmowanego stanowiska służbowego. Do osobistych uprawnień każdego urzędnika przysługujących z tytułu urzędowania należało prawo do uposażenia, które w odróżnieniu od prywatnoprawnego stosunku pracy oznaczało nie tylko prawo do wynagrodzenia pieniężnego $\mathrm{w}$ zamian za świadczoną pracę, ale także prawo do otrzymania dodatków służbowych, zwrotu wydatków poniesionych przez urzędnika $w$ związku $z$ pelnieniem shużby, prawo do zachowania pensji $w$ okresie pozostawania poza etatem urzędu, prawo do świadczeń emerytalnych po odejściu ze służby oraz prawo do zabezpieczenia materialnego bytu żony i dzieci urzędnika na wypadek jego śmierci. W końcu o publicznoprawnym charakterze urzędniczego stosunku shużby cywilnej świadczył charakter związanej $\mathrm{z}$ nią odpowiedzialności. W zależności od rodzaju i wagi przekroczenia urzędnicy ponosili odpowiedzial-

\footnotetext{
${ }^{5}$ M. G rom a d z a - G r ze gor zew ska, Narodziny polskich nauk administracyjnych, Warszawa 1985, s. 70; F. K as parek, Prawo polityczne ogólne, z uwzględnieniem austriackiego, razem ze wstẹpnq naukq ogólnq o państwie, t. II, Kraków 1877-1881, s. 700; A. O k ols ki, Wyklad prawa administracyjnego i prawa administracyjnego obowiqzujacego w Królestwie Polskim, t. I, Warszawa 1880 , s. 349.

${ }^{6}$ F. Ka s parek, Prawo polityczne..., t. II, s. 700-701; A. Okolski, Wyklad prawa..., t. I, s. $348-350$.
} 
ność: karno-sądową za przestępstwa urzędnicze, porządkową i dyscyplinarną za naruszenie obowiązków służbowych i cywilną za szkody wyrządzone przez nich podczas urzędowania?.

Podstawą funkcjonowania biurokracji rosyjskiej byla zasada legalizmu działania calego aparatu państwowego. Została ona sformulowana w art. 47 „Praw zasadniczych Cesarstwa Rosyjskiego” z 1832 r., który stanowil, że: Imperium Rosyjskie rzqdzi sie na podstawie obowiqzujacych, niezlomnych ustaw, ordynacji i statutów wydawanych przez samodzierżawnq wladze $e^{8}$. Zgodnie $\mathrm{z}$ zasadą legalizmu wszystkie organy państwowe miały działać $\mathrm{w}$ ramach prawa. Ponieważ jednak aż do 1906 r. prawo pochodziło wyłącznie od monarchy, nie mogło być poza nim żadnego innego prawnego punktu odniesienia, na przykład konstytucji, który umożliwialby organom państwowym utrzymanie względnej niezależności od woli cesarza. W tej postaci legalizm $z$ natury rzeczy był raczej konstrukcją teoretyczną, niż treścią praktyki życia państwowego w Rosji. Ministrowie rosyjscy nie mieli żadnej, nawet teoretycznej możliwości uniknięcia ingerowania $w$ sprawy należące do ich kompetencji, czy to bezpośrednio przez samego cesarza, czy też za pośrednictwem jego kancelarii. Po 1864 r. monarcha rosyjski nie miał już takiej możliwości jedynie wobec wymiaru sprawiedliwości, gdzie na przeszkodzie stała formalna, ale przestrzegana $w$ praktyce niezawisłość sądowa. Jednakże, poza sądownictwem, nad całym aparatem państwowym w Rosji nadal dominował cesarz jako najwyższy i suwerenny organ państwa, którego wola była utożsamiana $\mathrm{z}$ racją stanu państwa ${ }^{9}$.

Brak jakichkolwiek, poza monarchą, niezależnych instytucji kontrolujących funkcjonowanie administracji rosyjskiej prowadził $w$ konsekwencji do jej całkowitego upolitycznienia. Oznaczalo to takie wprzęgnięcie całego ustroju zarządu cywilnego $\mathrm{w}$ system policyjnego sterowania państwem, w którym kierunki i zakres działania administracji były dostosowywane na bieżąco do aktualnych preferencji politycznych państwa, a nie do potrzeb i oczekiwań obywateli. Zjawisku temu towarzyszylo stałe rozbudowywanie aparatu ścisłego

\footnotetext{
${ }_{7}$ W. Ostroży ński, Odpowiedzialność państwa za bezprawne dzialanie urzẹdników, Przegląd Sądowy i Administracyjny [Lwów] 1884, s. 366-367; A. Ok o1s k i, Wyklad prawa..., s. 369-380; F. K a s parek, Prawo polityczne..., t. II, s. 184-206; M. G rom adzka-Grzegorzewska, Narodziny polskich nauk..., s. 71-72; A. H e yl m a n, Rys procesu dyscyplinarnego sqdowego, Warszawa 1844, passim.

B Zbiór Praw, t. 1, 1837, s. 7.

${ }^{9}$ H. I z debski, Kolegialność $i$ jednoosobowość..., s. 67-68; Z. Chmielewski, Przejawy upolitycznienia administracji polskiej w XIX i XX wieku. Zarys problemu, ZN USz. 1992, nr 98 , s. 63.
} 
nadzoru i kontroli nad społeczeństwem oraz charakterystyczna dla monarchii absolutnych policyjna wszechobecność państwa. Powodowało to nie tylko ograniczenie praw obywateli, ale także wynaturzenia $w$ funkcjonowaniu machiny biurokratycznej. Nadmierne scentralizowanie aparatu biurokratycznego umożliwiało naczelnym wladzom resortowym ingerowanie $w$ kompetencje władz terenowych i podejmowanie decyzji nawet $w$ błahych sprawach, co prowadziło do znacznych opóźnień w załatwianiu spraw, jak i niedostosowania podjętych decyzji do warunków lokalnych, których urzędnicy szczebla centralnego nie byli $w$ stanie należycie poznać ${ }^{10}$.

Charakterystyczną cechą organizacji i funkcjonowania biurokracji rosyjskiej była zasada jednoosobowego kierownictwa urzędów. Została ona wprowadzona w organach zarządu cywilnego wszystkich szczebli na początku XIX w. i przetrwała do końca istnienia administracji cywilnej Cesarstwa. Zasada ta w warunkach państwa absolutnego stanowiła dla władz centralnych w Petersburgu dogodny środek oddziaływania na organy administracji terenowej, gdyż ułatwiała nadzór nad ich działalnością i stwarzała możliwość bezpośredniego dyscyplinowania kadr urzędniczych niższych szczebli. Przyjęcie jej w rosyjskim systemie biurokratycznym powodowało jednak nadmierna koncentracje kompetencji decyzyjnych $w$ rękach pojedynczych urzędników - szefów poszczególnych organów zarządu cywilnego. Ministrowie, gubernatorzy i naczelnicy powiatów rozstrzygali osobiście w zasadzie o wszystkich sprawach należących do właściwości podległych im urzędów. Nawet utrzymanie kolegialnej formy działania rządów gubernialnych nie podważało zasady jednoosobowego kierownictwa w stosunku do gubernatorów, gdyż ci ostatni nie tylko przewodniczyli obradom rządów gubernialnych, ale także mianowali ich członków i zatwierdzali wszystkie istotne ich postanowienia. $Z$ formalnego punktu widzenia, przyjęcie zasady jednoosobowego kierownictwa sprowadzało funkcje pozostałych pracowników urzędu do roli personelu pomocniczego - przybocznego biura naczelnika urzędu. W praktyce jednak zapewnienie sprawnego funkcjonowania całego aparatu zarządu cywilnego wymuszało konieczność przeprowadzenia w każdym urzędzie wewnętrznej dekoncentracji czynności administracyjnych, która polegała na delegowaniu części kompetencji naczelników urzędów na podległych im urzędników. W rzeczywistości więc główny ciężar prowadzenia spraw spoczywał w każdym urzędzie na radcach, referentach $\mathrm{i}$ innych urzędnikach kierujących poszczególnymi wydziałami i referatami. Prawo do ostatecznej decyzji pozostawało jednak nadal w rękach szefów urzędów ${ }^{11}$.

${ }^{10}$ Z. Chmielewski, Przejawy upolitycznienia..., s. 63, 72-73; H. I z debski, Historia administracji, s. 18-19.

$"$ Z. Ch mi el e w s ki, Narodziny i rozwój biuralizmu..., s. 26-27; L. J a śk i e w ic z, Administracja carska a samorząd terytorialny w epoce Aleksandra III, KH 1978, nr 2, s. 288-290; H. I zd e b sk i, Historia administracji, s. 42-43. 
Przedstawione wyżej zasady organizacji i funkcjonowania rosyjskiej biurokracji zostały wprowadzone do organów zarządu cywilnego w Królestwie Polskim równocześnie $\mathrm{z}$ reorganizacją miejscowego aparatu administracyjnego po powstaniu styczniowym. W efekcie działań unifikacyjnych i likwidacji odrębności administracyjnej Królestwa Polskiego wszystkie nowo utworzone, jak i zreformowane organy miejscowego zarządu cywilnego zostały podporządkowane właściwym resortowo władzom centralnym w Petersburgu. W ten sposób organy administracji cywilnej Królestwa stały się częścią zintegrowanego aparatu administracji lokalnej Cesarstwa. Brak odrębnych centralnych władz administracyjnych w Królestwie po powstaniu styczniowym spowodował równocześnie wzrost znaczenia organów średniego szczebla zarządu cywilnego, zwlaszcza urzędów gubernialnych, które od tego czasu stały się siłą napędową rozwoju biurokracji rosyjskiej w guberniach Królestwa Polskiego, $a \dot{z}$ do wybuchu I wojny światowej. Nowe ustawodawstwo o zarządzie gubernialnym $\mathrm{i}$ powiatowym $\mathrm{z}$ grudnia $1866 \mathrm{r}$. wprowadziło do ustroju organów zarządu cywilnego Królestwa zasade jednoosobowego kierownictwa urzędów. W sprawach wymagających szybkiej decyzji i egzekutywy taką władzę otrzymali gubernatorzy i naczelnicy powiatów. Ponadto urzędnicy ci $w$ pełni kontrolowali działalność podległych im rządów gubernialnych i zarządów powiatowych. W $1866 \mathrm{r}$. narzucono również organom administracji cywilnej w Królestwie Polskim rosyjską procedurę administracyjną i rosyjski system wewnętrznej dekoncentracji czynności urzędowych ${ }^{12}$.

W obowiązkach urzędników zarządzających kancelariami i wydziałami poszczególnych urzędów eksponowano ich pośredniczącą rolę pomiędzy gubernatorem a urzędnikiem bezpośrednio załatwiającym daną sprawę. W ten sposób gubernator jako szef podległego mu urzędu zachowywał dla siebie pełną inicjatywę i nadzór nad koncepcyjną stroną postępowania administracyjnego. Podstawowe znaczenie dla toku urzędowania miało zaś współdziałanie między gubernatorem - szefem urzędu, oraz referentem prowadzącym sprawę a radcą, asesorem czy innym urzędnikiem kierującym określonym wydziałem, występującym tu $\mathrm{w}$ roli pośrednika. W miarę upływu czasu wewnętrzny podział kompetencji w poszczególnych urzędach zaczął obejmować także czynności aktotwórcze. Na referentów spadał obowiązek prowadzenia dziennika podawczego (tzw. opisi dielam) i skorowidza alfabetycznego

12 Dziennik Praw, t. 66, s. 157; A. N i k if or u k, Kancelaria Rzqdu Gubernialnego Lomżyńskiego $z$ lat 1867-1918, Archeion 1984, R. LXVIII, s. 199; A. A jnenkie1, B. Leśnodorski, W. R os to c ki, Historia ustroju Polski 1764-1939, Warszawa 1970, s. 48; A. K o r ob ow i c z, W. Witkowski, Ustrój $i$ prawo na ziemiach polskich. Od rozbiorów do odzyskania niepodleglości, Lublin 1994, s. 113-114; Z. Ch m i l l w sk i, Narodziny i rozwój biuralizmu..., s. 27. 
załatwianych spraw. Zmniejszał się natomiast we wszystkich urzędach udzial kancelistów w procesie aktotwórczym, zawężając się jedynie do prac czysto technicznych ${ }^{13}$. Pozostawienie referentów prowadzących poszczególne sprawy urzędowe i posiadających bezpośredni kontakt z petentami urzędu w pełnej dyspozycji gubernatora - szefa urzędu gubernialnego, stwarzało dla władz carskich dogodne warunki realizowania ekspansywnych funkcji rosyjskiej administracji cywilnej średniego szczebla w guberniach Królestwa Polskiego. Zależni od gubernatorów urzędnicy referujący poszczególne sprawy urzędowe działali nie tyle zgodnie $\mathrm{z}$ ogólnie obowiązującymi zasadami postępowania administracyjnego czy racjonalnymi wymogami biurokracji, lecz raczej według aktualnych wytycznych swego zwierzchnika. W rezultacie pozycja urzędników średniego szczebla administracji rosyjskiej w Królestwie Polskim po powstaniu styczniowym nabierała bardziej jednoznacznego wymiaru politycznego niż to mialo miejsce w odniesieniu do urzędników administracji cywilnej pozostałych państw zaborczych. W podobnej sytuacji znaleźli się referenci niższych szczebli. Na przykład w zarządach powiatowych za ich poczynania odpowiadal naczelnik powiatu i jego zastępcy, jednoosobowo kierujący czynnościami urzędowymi należącymi do kompetencji podległych im zarządów ${ }^{14}$.

W konkluzji należy zatem stwierdzić, że pełne upolitycznienie rosyjskiego zarządu cywilnego w Królestwie Polskim po powstaniu styczniowym i brak niezawisłego od władzy wykonawczej sądownictwa administracyjnego stworzyły dogodne warunki do rozwoju niczym nieskrępowanej samowoli miejscowej biurokracji rosyjskiej, kosztem praw i wolności mieszkańców Królestwa.

${ }^{13}$ A. Nikif oruk, Kancelaria Rzqdu..., s. 194-207; Z. Chmielewski, Narodziny $i$ rozwój biuralizmu..., s. 30-31; A. K o piczyńsk a, Kancelaria gubernatora lomżyńskiego w latach 1867-1918. Funkcje i procesy aktotwórcze, Archeion 1988, R. LXXXIV, s. 38-41; J. Z a borowska, Ustrój, dzieje i akta kancelarii gubernatora warszawskiego z lat 1866-1917, Archeion 1969, R. LI, s. 143-145; A. Ajnenkie1, B. Leśnodorski, W. Rostocki, Historia ustroju..., s. 122.

${ }^{14} \mathrm{~F}$. R a m o tow $\mathrm{k}$ a, Uwagi o ksiegach kancelaryjnych $i$ archiwalnych urzęów polskich $i$ rosyjskich w XIX w., Studia Źródłoznawcze 1976, nr XXI, s. 69-71; Z. Ch mielewski, Narodziny i rozwój biuralizmu..., s. 28; J. Z a b or ow sk a, Uströj, dzieje..., s. 145; A. Ko piczyń sk a, Kancelaria gubernatora..., s. 41; A. Nikif oruk, Kancelaria Rzqdu..., s. 207. 